\title{
Small subunit ribosomal DNA characterization of an unidentified aurantiactinomyxon form and its oligochaete host Tubifex ignotus
}

\author{
C. Negredo*, E. Dillane, M. F. Mulcahy \\ Department of Zoology and Animal Ecology, National University of Ireland, Lee Maltings, Prospect Row, Cork, Ireland
}

\begin{abstract}
In this study, the small subunit (18S) ribosomal DNA gene from an aurantiactinomyxon form of unknown taxonomic position (A1) and from its aquatic oligochaete host (Tubifex ignotus) were characterized. Molecular sequence information on A1 was obtained to allow comparisons of this gene with known sequences from known myxosporean forms, and therefore to investigate possible relationships between this organism and its alternate myxosporean stage. Sequence data for the oligochaete host, together with morphological features, will allow reliable identification of this species in the future. Sequence data derived from the 18S DNA gene and data from other related or non-related organisms were analyzed and used to construct a phylogenetic tree. Phylogenetic studies provided an insight into the taxonomic position of A1. Sequence similarities within the 18S rDNA A1 gene and compared organisms indicated that A1 was most closely related to members of the suborder Variisporina (Myxidium lieberkuehni [Ml] and Sphaerospora oncorhynchi [So]). Clustering of the 3 organisms in the same branch was well supported by high bootstrap values (81\%). A1 showed higher similarities with sequences of Ml (approximately 80\%) than with So (approximately $79 \%$ ). Myxosporean sequence analysis indicated that phylogenetic arrangements do not support traditional classification based on morphological criteria of the spores, but rather support arrangement by tissue location. Marine actinosporeans Triactinomyxon sp. and Tetraspora discoidea were found to be associated with Platysporinid myxosporeans, supporting previous findings. In this study, 18S rDNA sequence data are generated for first time for the aquatic oligochaete T. ignotus. Phylogenetic 18S rDNA gene analyses performed with T. ignotus support and confirm existing morphological and molecular phylogenetic studies. Paraphyly of the Tubificidae family was noticed.
\end{abstract}

KEY WORDS: Aurantiactinomyxon · Tubifex ignotus $\cdot 18 \mathrm{~S}$ rDNA sequences · Phylogenetic analysis

Resale or republication not permitted without written consent of the publisher

\section{INTRODUCTION}

Most known members of the phylum Myxozoa are economically important parasites of fish. Members of this group have a complex life cycle involving 2 hosts, a fish, and an aquatic invertebrate host, which in most cases is an annelid. Wolf \& Markiw (1984) were the first to demonstrate this type of life cycle in Myxobolus cerebralis. The myxosporean spore stage, the final developmental stage in fish, when released, infects an oligochaete host (Tubifex tubifex), where it develops through an actinosporean stage. Similar life cycles for other myxosporean species (Kent et al. 1994) have been revealed by transmission studies.

Molecular analysis, based on ribosomal DNA sequences, has recently been applied to the study of myxosporeans. Using comparative sequence analysis, phylogenetic relationships between the phylum Myxozoa and the Metazoa have been clarified, and the complex myxosporean life cycle of 2 alternating forms supported. Sequence data analysis derived from comparative analysis of small subunit ribosomal DNA (SSU rDNA) gene have also been employed to develop DNA-based specific probes for diagnostic purposes, 
e.g. Myxobolus cerebralis (Andree et al. 1998, Antonio et al. 1998), Ceratomyxa shasta (Bartholomew et al. 1997), Tetracapsula bryosalmonae (Saulnier \& de Kinkelin 1997, Kent et al. 1998). PCR (polymerase chain reaction) and/or ISH (in situ hybridization) assays have been used for this purpose.

The phylum Myxozoa was previously classified within the Protozoa Grassé 1970. Phylogenetic analysis of the SSU rDNA revealed, however, that myxozoans have a metazoan origin (Smothers et al. 1994, Siddall et al. 1995, Schlegel et al. 1996). While Siddall et al. (1995) proposed a relationship with the Cnidaria, Schlegel et al. (1996) and Smothers et al. (1994) indicated a close relation to the bilaterians. Recent phylogenetic and morphological data have shown that myxozoans are closely related to Cnidaria (Kent et al. 2001).

The relationship between the actinosporean and myxosporean forms of Myxobolus cerebralis was confirmed using molecular techniques derived from phylogenetic studies. Comparative analysis of the SSU rDNA sequences of the actinosporean and myxosporean stages was utilised for this purpose (Andree et al. 1997). Since then, similar studies in other myxosporean genera, using comparative sequence analysis of actinosporean and myxosporean stages, have demonstrated identity between actinosporean and myxosporean stages, confirming previous experimental transmission studies (Bartholomew et al. 1997, Lin et al. 1999).

To date about 1300 myxosporean species and 40 actinosporean types have been identified (Lom \& Dykova 1992, 1995) and the numbers of each are increasing. Until recently actinosporeans and myxosporeans were identified and classified mainly on the basis of morphological features of the myxosporean and actinosporean spores and developmental stages.

Molecular studies suggested that spore morphology was an unreliable basis for establishing phylogenetic Myxozoa relationships, indicating conflicting arrangements between taxa. In some studies, criteria such as tissue specificity, geographic location and/or development have been demonstrated to be better than spore morphology as indicators of phylogenetic relationships between taxa (Hervio et al. 1997, Andree et al. 1999a, Kent et al. 2001). Salim \& Desser (2000) suggested that morphological features may be used as criteria for establishing evolutionary relationships when used in conjunction with molecular studies. To date, only a few molecular phylogenetic studies have included both myxosporean and actinosporean stages (Xiao \& Desser 2000a,b, Kent et al. 2001).

More sequence data on myxosporean and actinosporean stages are necessary not only to provide a better understanding of phylogeny of these organisms but also to facilitate actinosporean-myxosporean matches for the elucidation of unknown myxosporean life cycles. Although it still has to be demonstrated that all myxosporean marine and freshwater parasites follow a complex actinosporean-myxosporean life cycle, a similar type of life cycle can be assumed for most members of the phylum Myxozoa.

Recent molecular approaches applied to phylogenetic and life cycle studies have provided sequence data from the SSU rDNA sequences of a number of representatives of different myxosporean genera: Ceratomyxa (Bartholomew et al. 1997), Henneguya (Smothers et al. 1994, Sidall et al. 1995, Kent et al. 1996, 2001, Hervio et al. 1997, Lin et al. 1999, Hanson et al. unpubl. [H. ictaluri; GenBank AF195510 unpublished sequence]), Kudoa (Kent et al. 1996, Hervio et al. 1997), Myxidium (Smothers et al. 1994, Schlegel et al. 1996) and Myxobolus (Smothers et al. 1994, Andree et al. 1999a,b, Kent et al. 2001). SSU rDNA sequence data have been determined from only a small number of actinosporean stages, representatives of the aurantiactinomyxon (Lin et al. 1999, Pote et al. 2000) and triactinomyxon (Andree et al. 1997) collective groups. Also, marine actinosporeans from the triactinomyxon group and the actinosporean type Tetraspora discoidea (Hallet \& Lester 2000; Triactinomyxon sp. GenBank number AF306792 and T. discoidea AF306793 unpublished sequences) have been provided. The availability of these data allows comparative sequence analysis, and thus determination of genetic relatedness.

In a previous study, an aurantiactinomyxon form A1 infecting the aquatic oligochaete host Tubifex ignotus was described form a river system in southwest Ireland (Negredo \& Mulcahy 2001a). Morphologically and morphometrically A1 resembles the large form of Aurantiactinomyxon pavinsis, a parasite of the oligochaete Stylodrilus heringianus described by Marques in 1984 in France (Marques 1984). High prevalence of infection was found for actinosporean type A1, which was recorded from all the sampling sites in abundant numbers. Studies on the myxosporean fauna of fish in this river have demonstrated the presence of several myxosporean species (O'Flynn 1998). All have unknown life cycles.

The aims of the present study were (1) to obtain sequence information of the 18S rDNA gene from the aurantiactinomyxon $\mathrm{A} 1$; (2) compare this sequence with other known 18S available sequences from related and non-related myxosporean species and actinosporean stages, to elucidate the phylogenetic relationship among these organisms; and (3) to look for the possible relationship of A1 to an alternate myxosporean stage.

The study of actinosporean parasites has become essential to the understanding of myxosporean life cycles. However, transformation into an actinosporean stage requires the involvement of an annelid host. 
Understanding of the ecology of these hosts is necessary for the effective control of important myxosporean diseases. Thus, the reliable identification of oligochaete species becomes essential. The main morphological criteria used to distinguish within or between Oligochaeta taxa are either the location of the male genital organs or structural features of the chaetae. However, morphological identification within members in the order Tubificidae can be difficult especially within the genus Tubifex. Molecular studies using 16S mitochondrial rDNA sequences have demonstrated that the criteria used to distinguish between species of this genus are inadequate. Sturmbauer et al. (1999) and Beauchamp et al. (2001) have described several lineages of morphologically undistinguished species of Tubifex tubifex in Europe and North America. Therefore, (4) the molecular characterization of T. ignotus, the oligochaete host of aurantiactinomyxon A1 form, was a further objective of this work.

\section{MATERIALS AND METHODS}

Source and isolation of material. The aquatic oligochaete Tubifex ignotus was obtained from mud material collected from the lower reaches of the Cloonee system river in southwest Ireland (Negredo \& Mulcahy 2001a). The material was transported to the laboratory in plastic bags containing a small amount of river water. On arrival, sediments with the river water were placed into aerated containers pending examination. Oligochaetes were separated from the sediments by gently washing the sediments through a wire $500 \mu \mathrm{m}$ mesh sieve, which removed the large particles and debris.

Oligochaetes were placed individually in 96-well plates with $100 \mu \mathrm{l}$ filtered dechlorinated tap water per well (Yokoyama et al. 1991). Oligochaete specimens were rinsed several times in distilled water prior to inclusion in the wells. Water in the wells was changed daily. Actinosporeans released from the oligochaetes were removed from wells and counted. The number of released actinosporeans was estimated by counting the number of actinosporeans in $20 \mu \mathrm{l}$ suspension. Examination and identification of aurantiactinomyxon type A1 and its host Tubifex ignotus were performed as described by Negredo \& Mulcahy (2001a). Spore characteristics for aurantiactinomyxon A1 are given in that report.

DNA extractions. Actinosporean spores: Actinosporean A1 spores, from oligochaetes, were washed in distilled water twice by rinses and low-speed centrifugations $(500 \times g)$. Then, spores were collected by brief pelleting, resuspended in small volumes $(20 \mu \mathrm{l})$ of sterile distilled deionised water, and counted. Freshly released spores were processed either immediately, or within $3 \mathrm{~d}$ stored at $4^{\circ} \mathrm{C}$. DNA from actinosporean samples was extracted using sodium dodecyl sulfate (SDS)/Proteinase K digestion followed by phenol/ chloroform extraction. Prior to DNA isolation, spores were concentrated by centrifugation $(1000 \times g)$ for $10 \mathrm{~min}$, and the supernatant removed. Actinosporeans (approximately 3000 spores) were resuspended in a volume of lysis buffer solution $(150 \mu \mathrm{l})$ consisting of $100 \mathrm{mM} \mathrm{NaCl}, 10 \mathrm{mM}$ Tris, pH 7.6, $10 \mathrm{mM}$ ethylenediamine tetraacetic acid (EDTA) and $0.2 \%$ SDS. Proteinase K (Sigma) was added to the lysate solution to a final concentration $0.1 \mathrm{mg} \mathrm{ml}^{-1}$. The mixture was incubated at $57^{\circ} \mathrm{C}$ for $30 \mathrm{~min}$ and was extracted twice with phenol/chloroform procedure, followed by 1 chloroform-isoamyl alcohol extraction. After cell lysis, equal volumes of phenol and chloroform, isoamyl alcohol (24:1) were added to the digested sample and mixed gently on a rocker platform for $60 \mathrm{~min}$. Samples were then centrifuged at high speed $(10000 \times g)$ for $10 \mathrm{~min}$. The top layer, containing the nucleic acids, was removed with a wide-bore pipette. After 2 sequential extractions of the solution with equal volumes of phenol and chloroform, ending with a single treatment with chloroform-isoamyl alcohol, the DNA was precipitated with 2 volumes of $100 \%$ ethanol at $-20^{\circ} \mathrm{C}$ and $1 / 10$ volume of $5 \mathrm{M} \mathrm{NaCl}$. To allow DNA to precipitate, samples were placed at $-40^{\circ} \mathrm{C}$ and left overnight. The DNA was pelleted by centrifugation of the sample for $1 \mathrm{~h}$. Then the alcohol was removed, and the DNA washed once with $70 \%$ ethanol at $-20^{\circ} \mathrm{C}$. After a centrifugation step at $10000 \times g$ for $10 \mathrm{~min}$, the supernatant was decanted off and the pellet allowed to air dry for $20 \mathrm{~min}$ and resuspended in sterile distilled deionised water $(20 \mu \mathrm{l})$. Samples were allowed to resuspend at room temperature for $2 \mathrm{~h}$ prior storing at $-40^{\circ} \mathrm{C}$

Oligochaete samples: Tubifex ignotus specimens, preserved in absolute ethanol and stored at $-40^{\circ} \mathrm{C}$ until use, were the DNA source. After collection, and prior to fixation, oligochaete samples were rinsed several times in distilled sterile water. DNA from the oligochaete samples was also extracted using a Proteinase $\mathrm{K}$ digestion followed by the phenol/chloroform extraction procedure. Oligochaete specimens stored in ethanol were blotted in filter paper prior to tissue lyses to get rid of excess ethanol. Then, to help digestion of the tissue, the oligochaete was cut into small pieces using a sterile scalpel. Lysis of oligochaete tissues was performed with cetyl trimethyl ammonium bromide (CTAB) digestion buffer; $200 \mu$ of CTAB lysis buffer (100 mM Tris- $\mathrm{HCl}_{1} \mathrm{pH} 8 ; 1.4 \mathrm{M} \mathrm{NaCl} ; 20$ mM EDTA; $2 \%$ CTAB) were used per $\mathrm{mg}$. Proteinase $\mathrm{K}$ was added to the sample to a final concentration of $2 \mathrm{mg} \mathrm{ml}^{-1}$, and incubated approximately $20 \mathrm{~h}$ at $37^{\circ} \mathrm{C}$. 
Phenol and chloroform extraction was performed as previously described for the actinosporean spores. The DNA was precipitated with 2 volumes of $100 \%$ ethanol at $-20^{\circ} \mathrm{C}$ and $1 / 10$ volume of $5 \mathrm{M} \mathrm{NaCl}$. Samples were allowed to precipitate at $-20^{\circ} \mathrm{C}$ for $1 \mathrm{~h}$. After centrifugation $(10000 \times g)$ for $20 \mathrm{~min}$, the pellet was washed with $70 \%$ ethanol at $-20^{\circ} \mathrm{C}$. The DNA pellet was dried (air dry) for about $20 \mathrm{~min}$, and resuspended in a small volume $(40 \mu \mathrm{l})$ of sterile distilled deionised water. DNA was allowed to resuspend at room temperature for a few hours prior to storing at $-40^{\circ} \mathrm{C}$.

PCR amplification of SSU rDNA. 18S rDNA gene sequences were amplified using the universal primers $18 \mathrm{e}$ (forward primer) of sequence 5'-CTGGTTGATTCTGCCAGT-3' and $18 \mathrm{~g}$ (reverse primer) of sequence 5'-CGGTACTAGCGACGGGCGGTGTG-3' (Hillis \& Dixon 1991). Primers were supplied by MWGBiotech $^{\mathrm{TM}}$. Universal primers amplified a fragment of about 1800 base pairs (bp).

PCR amplifications were performed in a total volume of $50 \mu \mathrm{l}$. The reaction mixture consisted of $1 \times \mathrm{PCR}$ buffer (Tris-Cl, $\mathrm{KCl},\left(\mathrm{NH}_{4}\right)_{2} \mathrm{SO}_{4}, 15 \mathrm{mM} \mathrm{MgCl}_{2}, \mathrm{pH} 8.7$ $\left[20^{\circ} \mathrm{C}\right]$ ) (Quiagen), $5 \mu \mathrm{M}$ tetrametyl ammonium chloride, $200 \mu \mathrm{M}$ of each deoxynucleotide tri-phosphate (dNTP) (Quiagen), $40 \mathrm{pmol}$ of the reverse and forward primer and $2 \mathrm{U}$ of thermostable DNA polymerase (Quiagen). DNA amplifications were performed in a thermo cycler (Hybaid OMNI-ETM).

PCR conditions for the actinosporean spores were as follows: after an initial 6 min denaturation step at $96^{\circ} \mathrm{C}$, samples were taken through 40 amplification cycles, each consisting of a 1 min denaturation step at $95^{\circ} \mathrm{C}$, a $1 \mathrm{~min}$ primer annealing step at $45^{\circ} \mathrm{C}$, and a $3 \mathrm{~min}$ extension step at $72^{\circ} \mathrm{C}$. A prolonged extension step of 5 min at $72^{\circ} \mathrm{C}$ completed each reaction.

Optimum PCR conditions for the oligochaete were as follows: An initial denaturation step at $95^{\circ} \mathrm{C}$ for $5 \mathrm{~min}$ incubation followed by 35 amplification cycles, each consisting of a $1 \mathrm{~min}$ denaturation step at $95^{\circ} \mathrm{C}$, a $2 \mathrm{~min}$ primer annealing step at $45^{\circ} \mathrm{C}$, and a 4.5 min extension step at $72^{\circ} \mathrm{C}$. As with the spores, a prolonged extension step of $5 \mathrm{~min}$ at $72^{\circ} \mathrm{C}$ completed each reaction.

PCR products were analyzed by electrophoresis on a $2 \%$ agarose gel.

Cloning of PCR products. PCR amplified DNA fragments were inserted into the pGEM $^{\circledR}$-T (System I) plasmid vector (Promega) using the T4-ligase enzyme (included in the vector kit). The ligation reaction was performed in $5 \mu$ of $2 \times$ T4 DNA ligase buffer $(60 \mathrm{mM}$ Tris- $\mathrm{HCl}, \mathrm{pH} 7.8,20 \mathrm{mM} \mathrm{MgCl} 2,20 \mathrm{mM}$ DTT [dithiothreitol], $1 \mathrm{mM}$ ATP $10 \%$ PEG [polyethylene glycol]), $1 \mu \mathrm{l}$ of $50 \mathrm{ng}$ vector, $1 \mu \mathrm{l}$ of PCR product and $3 \mathrm{U}$ of T 4 DNA ligase. Deionised water was added to a final volume of $10 \mu \mathrm{l}$. The reaction was mixed gently and incubated overnight at $4^{\circ} \mathrm{C}$. The recombinant gen- erated plasmid was transformed into competent Escherichia coli DH5 $\alpha^{\mathrm{TM}}$ strain (GibcoBRL) cells according to the manufacturer's instructions. A $100 \mu \mathrm{l}$ transformation was performed ( $4 \mu$ l of ligation product per $100 \mu \mathrm{l}$ of competent cells). The transformants obtained were cultured on Luria-Bertaini broth (LB) agar plates supplemented with $100 \mu \mathrm{g} \mathrm{ml}^{-1}$ of ampicillin according to Sambrook et al. (1989). Presence of inserts was confirmed by screening transformant colonies by using PCR. PCR amplifications were performed in a total volume of $20 \mu$ l. The reaction consisted of: $2 \mu \mathrm{l} 10 \times$ reaction buffer, $1.2 \mu \mathrm{l} \mathrm{MgCl}_{2}$ (25 mM), $4 \mu \mathrm{ldNTP}$ 's (1.25mM), $1 \mu \mathrm{l}$ of pUC 18 universal sequencing primers $(20 \mu \mathrm{M})$ forward (5'-GTTGTAAAACGACGGCCAGT-3') and reverse primers (5'-AACAGCTATGACCATGATTA-3') and $0.5 \mathrm{U}$ of thermostable DNA polymerase (Quiagen). Two $\mu$ of the inoculum was used in the PCR assay. DNA amplifications were performed in a thermocycler (Hybaid OMNI-ETM). Reactions were initiated by a 2 min incubation at $95^{\circ} \mathrm{C}$ followed by 30 amplification cycles, each consisting of a $30 \mathrm{~s}$ denaturation step at $95^{\circ} \mathrm{C}$, a $30 \mathrm{~s}$ primer annealing step at $45^{\circ} \mathrm{C}$, and a $60 \mathrm{~s}$ extension step at $72^{\circ} \mathrm{C}$. Products were run on $2 \%$ agarose gel. Plasmid DNA was purified from overnight bacterial cultures by using the Wizard ${ }^{\circledR}$ Plus SV Minipreps DNA purification system (Promega) and following the manufacturer's instructions.

Sequencing analysis. Sequencing was carried out using a Thermo Sequenase fluorescent-labelled primer cycle sequencing kit with 7-deaza-dGTP (Amershan Pharmacia Biotech) according to the manufacturer's protocol. Sequencing reaction products were analyzed on a $6 \%$ polyacrylamide gel $0.25 \mathrm{~mm}$ thick, using a LiCor 4200 automated DNA sequencer.

Selection of specific primers and sequencing of internal rDNA sequences: Sequences across the insert were completed by using primers complementary to internal forward and reverse strand regions of the target rDNA sequences. Synthetic oligonucleotides were designed from A1 and Tubifex ignotus partial sequences, and tested for secondary self-complementarity, homodimer or heterodimer formation using the Primer 3.0 design computer software (genome. wi.mit.edu/genomes_software/other/primer3.html). Primers were supplied by MWG-Biotech AG. Primer sequences $\left(5^{\prime}\right.$ to $3^{\prime}$ orientation) are given below: aurantiactinomyxon primers forward (A1f: GCCGCGGTAATTCCAGCTCTAA) and reverse (A1r: GGTGCCCTTCCGTCAATTCCTT) and $T$. ignotus primers forward and reverse (Tif: GCCGCGGTAATTCCAGCTCCA) (Tir: CCGCGGGGTCATTAGATCAACG). Sequencing reactions were performed as described above followed by automated analysis (LiCor 4200). Digitised images of DNA sequences obtained on the 
automated sequencer were read from polyacrylamide gel images using a Base ImagR Image Analyis software (MWG-Biotech ${ }^{\mathrm{TM}}$ ).

Sequencing alignments and phylogenetic analysis. 18S rDNA sequences were edited using a GeneTool Lite version 1.0 software sequencer editor (Biotools, Advanced Bioinformatic Solutions; available at www. doubletwist.com). A consensus sequence was developed by alignment of 2 replicates, which showed identity within sequences. Completed sequences were blasted (GenBank BLAST [Basic Local Alignment Search Tool]; Altschul et al. 1990, 1997) ${ }^{1}$ to search for similar sequences, and to confirm that sequences obtained for the actinosporean spore and for the oligochaete species were related to members belonging to the Myxozoa and to the Annelida (Oligochaeta), respectively.

The sequences of A1 and Tubifex ignotus were then aligned with homologous 18S rDNA gene sequences from a selected number of organisms using the multialigment software CLUSTAL W (version 1.81) (Thompson et al. 1994) with default gap penalty settings. The A1 sequence was compared with SSU rDNA molecular data available from several members of the Myxozoa, as well as from the outgroup Polypodium hydriforme, a cnidarian species. These data were obtained from GenBank. T. ignotus was compared with that available for other Oligochaeta. The hirudinean Hirudo medicinalis was used as an outgroup for phylogenetic oligochaete studies.

Species for phylogenetic analysis were selected according to the length of rDNA gene sequences available and the grade of sequence similarity defined by BLAST search. Some other species representative of different genera or groups were also included to define their relatedness to the studied organisms.

By CLUSTAL analysis the percentage of identity among compared organisms was calculated. Sequence data for analysis was restricted to SSU rDNA regions that were available in all included species. Then phylogenetic analysis between related organisms were carried out using the Molecular Evolutionary Genetics Analysis software program (MEGA version) developed by Kumar et al. (1993). Genetic distances measurements were estimated using Jukes-Cantor methodology (Jukes \& Cantor 1969), calculated with deletion of gaps or missing data. Phylogenetic relatedness between compared organisms was inferred from genetic distance data, using the neighbour-joining method (Saitou \& Nei 1987) with statistical estimation of branch point validity shown as a bootstrap confidence levels. This method was used with 500 replicates.

${ }^{1}$ BLAST searches of nucleic acid data base at the electronic mail server: BLAST@ncbi.nlm.nih.gov

\section{RESULTS}

\section{PCR amplification of the SSU rDNA gene sequences}

The SSU rRNA gene of aurantiactinomyxon A1 and Tubifex ignotus were each amplified by using the conserved SSU rRNA universal primers 18e (5'-CTGGTTGATTCTGCCAGT3-') and $18 \mathrm{~g}$ (5'-CGGTACTAGCGACGGGCGGTGTG-3'). The amplified fragment of the aurantiactinomyxon A1 type resulted in an approximately $1900 \mathrm{bp}$ product. The oligochaete amplified fragments gave similar product sizes, between 1700 and $1800 \mathrm{bp}$.

\section{Cloning and sequencing analysis of PCR products}

The PCR products obtained from the aurantiactinomyxon spore and of its oligochaete host (Tubifex ignotus) were cloned into the pGEM $^{\circledR}$-T vector. PCR screening of obtained clones revealed a high number of transformed colonies containing the target inserts. Four positive clones were selected from each sample, and prepared for sequencing analysis. Plasmid DNA was isolated and purified from the Escherichia coli. Four purified plasmidDNA samples, 2 including cloning inserts corresponding to the aurantiactinomyxon spore and 2 for the oligochaete, were selected and sequenced.

Forward and reverse primers (pUC 18f and pUC 18r) specific to plasmid regions were used to obtain the sequences across the inserts for the actinosporean A1 and its oligochaete host Tubifex ignotus. A partial sequence of 1607 and $1499 \mathrm{bp}$ were initially generated for the arurantiactinomyxon form and its oligochaete host respectively. Sequences were completed by using designed primers complementary to internal regions of the target rDNA sequences. Complete nucleotide sequence for A1 consisted of $1946 \mathrm{bp}$ (GenBank accession number AF483598). In the case of Tubifex ignotus, the completed sequence for the 18S rDNA gene consisted of 1658 bp (GenBank accession number AF483597).

Each sequence was obtained for 2 replicates, indicating successful amplification and sequencing of the samples. Sequence analysis of 2 Escherichia coli transformants for each sample resulted in identical sequences.

\section{Sequencing alignments and phylogenetic analysis}

Aurantiactinomyxon A1

BLAST searches using the obtained aurantiactinomyxon sequence confirmed that the most similar sequences to the aurantiactinomyxon form correspond 
to $18 \mathrm{~S}$ rDNA gene sequences of members of the phylum Myxozoa. Myxosporean species and actinosporean form sequences, found in the GenBank by BLAST search, which produced significant alignements with sequence of A1 are listed in Table 1. The species are sorted by grade of similarity according to length of available sequences. The first species listed gave the most significant alignment.

The SSU rDNA regions of the aurantiactinomyxon form were aligned with known SSU rDNA gene homologous sequences of several myxosporean species and actinosporean forms selected from the BLAST search. Representative myxosporean species from different genera such as Henneguya, Sphaerospora, Ceratomyxa, Myxidium and Myxobolus were selected

Table. 1. List of 18S rDNA gene sequences with similarities to aurantiactinomyxon A1 18S rDNA sequence as defined by BLAST search. Myxosporean species and actinosporean form names, GenBank accession number and nucleotide available length (in base pairs, bp) are given

\begin{tabular}{|c|c|c|}
\hline $\begin{array}{l}\text { Myxosporean species/ } \\
\text { actinosporean form }\end{array}$ & $\begin{array}{c}\text { GenBank } \\
\text { accession no. }\end{array}$ & $\begin{array}{l}\text { Nucleotide } \\
\text { length (bp) }\end{array}$ \\
\hline \multicolumn{3}{|l|}{ Myxidium lieberkuehni ${ }^{\mathrm{a}}$} \\
\hline$(\mathrm{Ml18})$ & ML16SLR1 & 2084 \\
\hline (Ml19) & ML16SLR2 & 2085 \\
\hline Sphaerospora oncorhynchi ${ }^{\mathrm{a}}$ & AF201373 & 1909 \\
\hline Henneguya exilis ${ }^{\mathrm{a}}$ & AF021881 & 2081 \\
\hline Aurantiactinomyxon mississippiensis ${ }^{\mathrm{a}}$ & AF021878 & 2087 \\
\hline Myxobolus squamalis ${ }^{\mathrm{a}}$ & U96495 & 1932 \\
\hline Myxobolus sp. ${ }^{\mathrm{a}}$ & U13830 & 1903 \\
\hline Triactinomyxon sp. ${ }^{\mathrm{a}}$ & AF306792 & 1751 \\
\hline Myxobolus pendula & AF186837 & 811 \\
\hline Myхobolus pseudokoi & AF186839 & 791 \\
\hline Myxidium sp. ${ }^{\mathrm{a}}$ & U13829 & 1879 \\
\hline Myxobolus martini & AF186836 & 778 \\
\hline Myxobolus algonquinensis & AF186833 & 795 \\
\hline Myхobolus cerebralis & AF115255 & 1653 \\
\hline Myxobolus siddalli & AF186840 & 801 \\
\hline Henneguya salmonicola ${ }^{\mathrm{a}}$ & $\mathrm{AF} 031411$ & 1950 \\
\hline Henneguya ictaluri & AF195510 & 2083 \\
\hline Myxobolus algonquinensis & AF186834 & 794 \\
\hline Myxidium truttae $\mathrm{a}^{\mathrm{a}}$ & AF201374 & 1879 \\
\hline Myxobolus xiaoi & AF186843 & 861 \\
\hline Myxobolus insidiosus & U96494 & 1937 \\
\hline \multirow[t]{3}{*}{ Myxobolus cerebralis } & AF115253 & 1652 \\
\hline & AF115254 & 1654 \\
\hline & MCU96493 & 1614 \\
\hline Myxobolus algonquinensis & AF186832 & 777 \\
\hline Myxobolus cerebralis & MCU96492 & 1937 \\
\hline Myxobolus neurobius & $\mathrm{AF} 085180$ & 1611 \\
\hline Myxobolus pseudodispar & AF380144 & 1551 \\
\hline Myxobolus cyprini ${ }^{\text {a }}$ & AF380140 & 1554 \\
\hline Myxobolus portucalensis & AF085182 & 1656 \\
\hline Myxobolus sandrae & AF085181 & 1609 \\
\hline Ceratomyхa shasta ${ }^{a}$ & AF001579 & 1643 \\
\hline Tetraspora discoidea ${ }^{\mathrm{a}}$ & AF306793 & 1793 \\
\hline
\end{tabular}

for alignments. The $18 \mathrm{~S}$ rDNA gene sequences of 3 actinosporean forms corresponding to the collective groups aurantiactinomyxon, triactinomyxon, and tetraspora were included in the alignments. 18S rDNA gene sequences from the myxosporean Tetracapsula bryosalmonae (PKX organism) (U70623) and the cnidarian outgroup species Polypodium hydriforme (U37526) were also included, and compared to the aurantiactinomyxon form of this study. 18S rDNA gene selected sequences are shown in Table 1.

Genetic distances among compared organisms were calculated from investigated alignments (Table 2) and the taxonomic position of A1 in relation to compared organisms was defined. A phylogenetic tree was constructed from the genetic data obtained from comparisons of homologous rDNA sequences from these organisms, using the neighbor-joining distance analysis method, and is shown in Fig. 1. Bootstrap values indicated in the figure are based upon 500 replicates.

Genetic distances among organisms indicated that the actinosporean A1 form of this study is more closely related to Myxidium lieberkuehni (Ml) and Sphaerospora oncorhynchi (So) genus than to other myxosporean species or actinosporean-compared forms. Identities between 18S rDNA gene sequences of aurantiactinomyxon A1 and those from compared organisms ranged from 55.3 to $79.9 \%$. The highest percentages were obtained for $\mathrm{Ml}(79.9 \% \mathrm{Ml18}, 79.6 \%$ Ml19) and So (78.6\%). These results confirmed those obtained by BLAST searches. Similarities between actinosporean sequences ranged from 73.7 to $77.6 \%$. The lowest percentages were obtained for the myxosporean Ceratomyxa shasta (Cs) (60.7\%) followed by Tetracapsula bryosalmonae $(\mathrm{Tb})(55.6 \%)$ and the cnidarian Polypodium hydriforme (Ph) (55.3\%) (Table 2).

A phylogenetic dendrogram (Fig. 1), constructed from genetic distances, defined the taxonomic position of aurantiactinomyxon A1 grouping with So and Ml. High bootstrap values of $81 \%$ supported this arrangement. As expected, M118 and Ml19 clustered together (sequences with $98.5 \%$ identity) with strong supported bootstrap values of $100 \%$. So show $90 \%$ sequence identity with Ml. Strong bootstrap values (100\%) also supported its relationship with $\mathrm{Ml}$.

The phylogenetic relationship within the remaining compared organisms showed that the aurantiactinomyxon A1, So and Ml18/M19 group separated from Myxobolus and Henneguya species and actinosporean compared forms, with high bootstrap values of $99 \%$. Although these 2 groups of organisms branched 
Table. 2. SSU rDNA genetic distances between selected organisms derived from comparisons of rDNA gene sequences. JukesCantor distances are shown below the diagonal. Numbers on top of columns and rows (1 to 17) indicate the organism name. 1: Myxidium lieberkuehni (Ml18); 2: Myxidium lieberkuehni (Ml19); 3: Henneguya exilis (He); 4: Aurantiactinomyxon mississippiensis (Am); 5: Triactinomyxon sp. (Tsp); 6: Tetraspora discoidea (Td); 7: Henneguya salmonicola (Hs): 8: Myxobolus cyprini (Mcy); 9: Myxobolus sp. (Msp); 10: Myxobolus squamalis (Msq); 11: Aurantiactinomyxon 1 (1); 12: Myxidium truttae (Mt); 13: Myxidium sp. (Myxsp); 14: Sphaerospora oncorhynchi (So); 15: Tetracapsula bryosalmonae (Tb); 16: Polypodium hydriforme (Ph); 17: Ceratomyxa shasta (Cs)

\begin{tabular}{|c|c|c|c|c|c|c|c|c|c|c|c|c|c|c|c|c|c|}
\hline & 1 & 2 & 3 & 4 & 5 & 6 & 7 & 8 & 9 & 10 & 11 & 12 & 13 & 14 & 15 & 16 & 17 \\
\hline 1 & & & & & & & & & & & & & & & & & \\
\hline 2 & 0.015 & & & & & & & & & & & & & & & & \\
\hline 3 & 0.226 & 0.231 & & & & & & & & & & & & & & & \\
\hline 4 & 0.229 & 0.236 & 0.039 & & & & & & & & & & & & & & \\
\hline 5 & 0.237 & 0.240 & 0.121 & 0.122 & & & & & & & & & & & & & \\
\hline 6 & 0.234 & 0.240 & 0.132 & 0.129 & 0.149 & & & & & & & & & & & & \\
\hline 7 & 0.238 & 0.242 & 0.234 & 0.235 & 0.228 & 0.236 & & & & & & & & & & & \\
\hline 8 & 0.249 & 0.251 & 0.231 & 0.234 & 0.252 & 0.235 & 0.210 & & & & & & & & & & \\
\hline 9 & 0.221 & 0.221 & 0.229 & 0.229 & 0.229 & 0.238 & 0.229 & 0.239 & & & & & & & & & \\
\hline 10 & 0.220 & 0.218 & 0.219 & 0.224 & 0.249 & 0.237 & 0.236 & 0.231 & 0.118 & & & & & & & & \\
\hline 11 & 0.201 & 0.204 & 0.243 & 0.249 & 0.263 & 0.224 & 0.243 & 0.258 & 0.244 & 0.245 & & & & & & & \\
\hline 12 & 0.218 & 0.219 & 0.256 & 0.259 & 0.263 & 0.266 & 0.265 & 0.263 & 0.228 & 0.246 & 0.244 & & & & & & \\
\hline 13 & 0.210 & 0.214 & 0.246 & 0.256 & 0.263 & 0.254 & 0.258 & 0.259 & 0.223 & 0.242 & 0.229 & 0.062 & & & & & \\
\hline 14 & 0.094 & 0.096 & 0.228 & 0.235 & 0.227 & 0.243 & 0.235 & 0.250 & 0.210 & 0.219 & 0.214 & 0.220 & 0.219 & & & & \\
\hline 15 & 0.433 & 0.447 & 0.470 & 0.472 & 0.476 & 0.442 & 0.475 & 0.432 & 0.472 & 0.472 & 0.444 & 0.426 & 0.435 & 0.438 & & & \\
\hline 16 & 0.417 & 0.426 & 0.424 & 0.416 & 0.421 & 0.445 & 0.480 & 0.448 & 0.433 & 0.439 & 0.447 & 0.383 & 0.393 & 0.403 & 0.357 & & \\
\hline 17 & 0.376 & 0.388 & 0.374 & 0.377 & 0.393 & 0.381 & 0.419 & 0.373 & 0.376 & 0.395 & 0.393 & 0.357 & 0.353 & 0.383 & 0.359 & 0.365 & \\
\hline
\end{tabular}

separately, both are more closely related than to $M y x-$ idium sp. (Myxsp) and M. truttae (Mt), which clustered together $(100 \%)$ in a separate branch supported by $100 \%$ confidence levels.

Henneguya salmonicola (Hs) and Myxobolus cyprini (Mcy), species from different genera, clustered together with strong bootstrap values of $99 \%$.

The branching of the actinosporean forms Tetraspora discoidea (Td) together with Henneguya exilis (He), Aurantiactinomyxon mississippiensis (Am) and Triactinomyxon sp. (Tsp) was strongly supported by a bootstrap value of $100 \%$, and the clustering of Tsp with He and Am with bootstrap values $95 \%$.

As was expected from the considerable genetic divergence observed for Ceratomyxa shasta (Cs), Tb, $\mathrm{Ph}$ among compared organisms, these species clustered separately from all the groups mentioned above,

Fig. 1. Phylogenetic tree inferred from genetic distances by the neighbour-joining method, showing taxonomic position of aurantiactinomyxon A1 form in relation to compared organisms. Numbers at nodes indicate bootstrap confidence levels. Scale bar $=0.05$ distance. He: Henneguya exilis; Am: Aurantiactinomyxon mississippiens; Tsp: Triactinomyxon sp.; Td: Tetraspora discoidea; Hs: Henneguya salmonicola; Mcy: Myxobolus cyprini; Msp: Myxobolus sp.; Msq: Myxobolus squamalis; 1: Aurantiactinomyxon 1; So: Sphaerospora oncorhynchi; Ml18: Myxidium lieberkuehni; Ml19: Myxidium lieberkuehni; Mt: Myxidium truttae; Myxsp: Myxidium sp.; Cs: Ceratomyxa shasta; Tb: Tetracapsula bryosalmonae; $\mathrm{Ph}$ : Polypodium hydriforme supported by strong bootstrap values of $100 \%$. Genetic distances among $\mathrm{Cs}, \mathrm{Tb}$ and $\mathrm{Ph}$ also indicated a considerable divergence between them. However, Tb and $\mathrm{Ph}$ showed to be more closely related than to $\mathrm{Cs}$ and clustered together (100\% bootstrap confidence value).

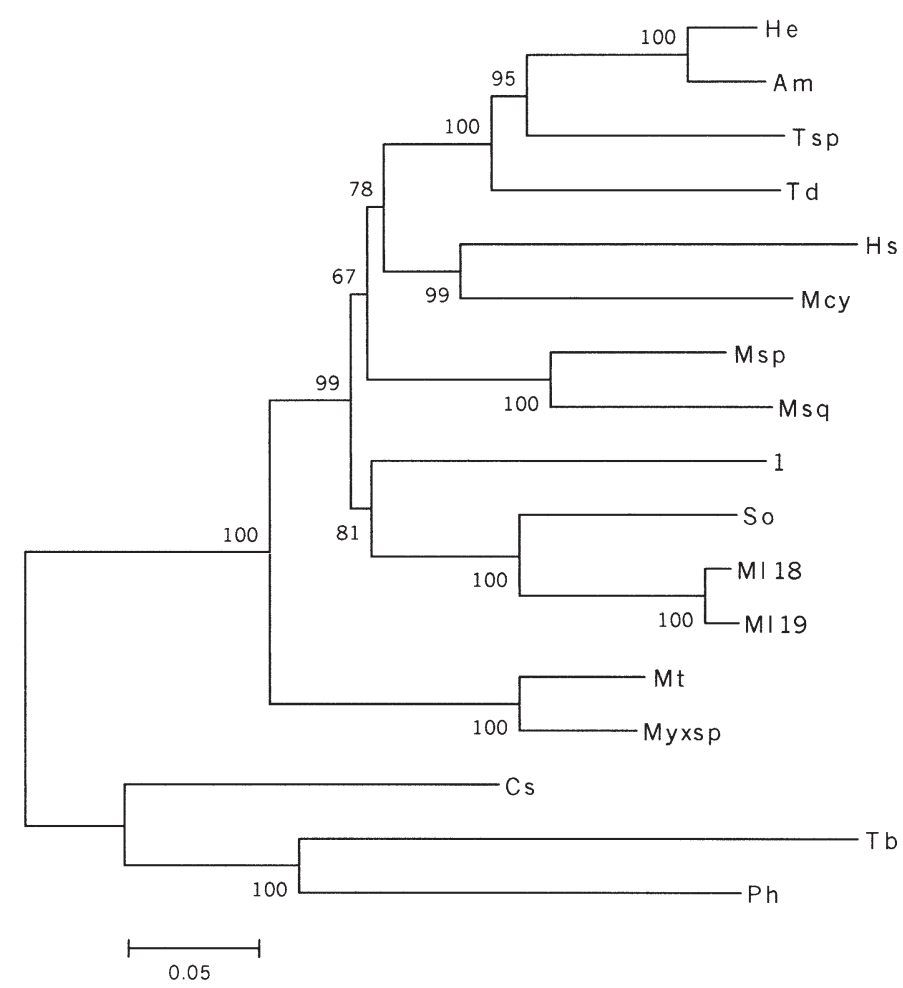




\section{Tubifex ignotus}

BLAST searches revealed sequence similarities of the 18S rDNA gene sequence obtained for Tubifex ignotus with $18 \mathrm{~S}$ rDNA gene sequences of several oligochaete members belonging to the Tubificidae,

Table 3. List of fifteen 18S rDNA gene sequences with similarities to Tubifex ignotus as defined by BLAST search. Oligochaete families, species name, GenBank accession number and nucleotide available length (in base pairs, bp) are given

\begin{tabular}{|c|c|c|c|}
\hline $\begin{array}{l}\text { Oligochaete family } \\
\text { (subfamily) }\end{array}$ & $\begin{array}{l}\text { Oligochaete } \\
\text { species }\end{array}$ & $\begin{array}{c}\text { GenBank } \\
\text { accession no. }\end{array}$ & $\begin{array}{l}\text { Nucleotide } \\
\text { length (bp) }\end{array}$ \\
\hline $\begin{array}{l}\text { Naididae } \\
\text { (complete) }\end{array}$ & Dero digitata $^{\mathrm{a}}$ & AF021879 & 1807 \\
\hline $\begin{array}{l}\text { Tubificidae } \\
\text { (Rhyacodrilinae) }\end{array}$ & Heterodrilus decipiens ${ }^{\mathrm{a}}$ & AF209455 & 1787 (partial) \\
\hline $\begin{array}{l}\text { Tubificidae } \\
\text { (Rhyacodrilinae) }\end{array}$ & Heronidrilus heronae $^{\mathrm{a}}$ & AF209454 & 1780 (partial) \\
\hline $\begin{array}{l}\text { Tubificidae } \\
\text { (Phallodrilinae) }\end{array}$ & Olavius tantulus $^{\mathrm{a}}$ & AF209460 & 1722 (partial) \\
\hline $\begin{array}{l}\text { Tubificidae } \\
\text { (Tubicinae) }\end{array}$ & Tubifex sp. ${ }^{\mathrm{a}}$ & TSU67145 & 1744 (partial) \\
\hline $\begin{array}{l}\text { Tubificidae } \\
\text { (Tubicinae) }\end{array}$ & Tubificoides bermudae ${ }^{a}$ & AF209467 & 1714 (partial) \\
\hline $\begin{array}{l}\text { Naididae } \\
\text { (complete) }\end{array}$ & Stylaria sp. ${ }^{\mathrm{a}}$ & U95946 & 1821 \\
\hline $\begin{array}{l}\text { Tubificidae } \\
\text { (Phallodrilinae) }\end{array}$ & Pirodrilus minutus $^{\mathrm{a}}$ & AF209463 & 1790 (partial) \\
\hline Tubificidae & Pectinodrilus molestus & AF209462 & 1767 (partial) \\
\hline Tubificidae & Bathydrilus litoreus & AF209456 & 1784 (partial) \\
\hline Tubificidae & Inanidrilus leukodermatus & AF209456 & 1717 (partial) \\
\hline Tubificidae & Olavious albidus & AF209461 & 1793 (partial) \\
\hline Tubificidae & Arktedrilus arcticus & AF209451 & 1719 (partial) \\
\hline Tubificidae & Thalassodrilides gurwitschi & i AFO9466 & 1699 (partial) \\
\hline Enchytraeidae & Fridericia tuberosa & AF209453 & 1745 (partial) \\
\hline
\end{tabular}

Naididae and Enchytraeidae families. The first 15 BLAST-defined species are listed in Table 3.

The SSU rRNA regions of selected oligochaete species (Shown in Table 3) and the outgroups Lumbriculus variegatus (AF209457) and Hirudo medicinalis (AF116011) were aligned and genetic distances calculated (Table 4). A phylogenetic dendrogram was inferred from genetic distance data, using the neighbour-joining method (Fig. 2).

The 2 most closely related species to Tubifex ignotus (T) were Tubifex sp. (TspTSU) and Tubificoides bermudae (Tbe). Genetic distance observed between $\mathrm{T}$ and the species TspTSU and Tbe were 99.2 and $99.4 \%$ respectively. These 2 species branched together with T. ignotus, measured by high bootstrap support of $95 \%$; and both clustered together with strong bootstrap support of $95 \%$.

The next most closely related species was Dero digitata (Dd) at 98.9\% sequence similarity followed by Pirodrilus minutus (Pm) and Heronidrilus heronae (Hh) both at $98.8 \%$. Identities between Heterodrilus decipiens (Hd), Stylaria sp., (St) and Olavius tantulus (Ot) ranged from 98.2 to $98.6 \%$. The dendrogram revealed high bootstrap values at nodes ranging between 81 to $98 \%$. However weak values of $57 \%$ were obtained for nodes connecting Naididae species, and Ot, Pm and Hd groups of $53 \%$ were nodes connecting all these species and group of Tubifex species and Tbe.

Table 4. SSU rDNA genetic distances between selected organisms derived from comparisons of rDNA gene sequences. JukesCantor distances are shown below the diagonal. Numbers on top of columns and rows (1 to 11) indicate the organism name. 1: Tubifex sp. (TspTSU); 2: Tubificoides bermudae (Tbe); 3: Dero digitata (Dd); 4: Stylaria sp. (St); 5: Heterodrilus decipiens (Hd); 6: Olavius tantulus (Ot); 7: Pirodrilus minutus (Pm); 8: Tubifex ignotus (T); 9: Heronidrilus heronae (Hh); 10: Lumbriculus variegatus $(\mathrm{Lv})$; 11: Hirudo medicinalis $(\mathrm{Hm})$

\begin{tabular}{|lcccccccccc|}
\hline & 1 & 2 & 3 & 4 & 5 & 6 & 7 & 8 & 9 & 10 \\
\hline 1 & & & & & & & & & & \\
2 & 0.008 & & & & & & & & \\
3 & 0.017 & 0.014 & & & & & & & \\
4 & 0.023 & 0.020 & 0.010 & & & & & & \\
5 & 0.018 & 0.014 & 0.013 & 0.018 & & & & & \\
6 & 0.020 & 0.020 & 0.017 & 0.022 & 0.011 & & & & \\
7 & 0.016 & 0.011 & 0.011 & 0.017 & 0.007 & 0.009 & & & \\
8 & 0.008 & 0.006 & 0.011 & 0.017 & 0.014 & 0.018 & 0.012 & & \\
9 & 0.015 & 0.013 & 0.012 & 0.017 & 0.012 & 0.014 & 0.012 & 0.012 & \\
10 & 0.056 & 0.055 & 0.053 & 0.056 & 0.054 & 0.058 & 0.054 & 0.055 & 0.093 \\
11 & 0.100 & 0.099 & 0.097 & 0.100 & 0.097 & 0.101 & 0.100 & 0.097 & 0.096 \\
\hline
\end{tabular}




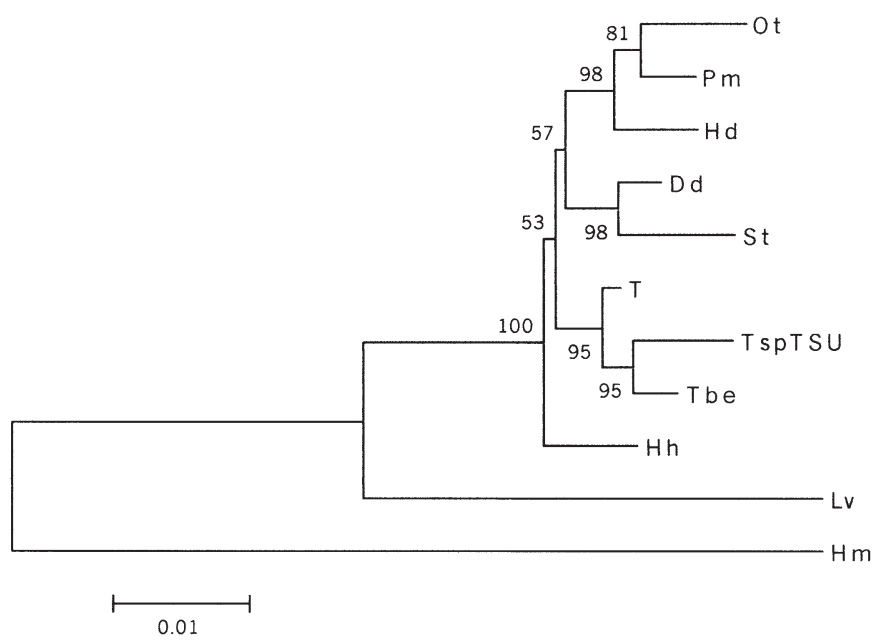

Fig. 2. Phylogenetic tree inferred from genetic distances by the neighbour-joining method showing taxonomic position of Tubifex ignotus in relation to compared organisms. Numbers at nodes indicate bootstrap confidence levels. Scale bar $=0.01$ distance. Ot: Olavius tantulus; Pm: Pirodrilus minutus; Hd: Heterodrilus decipiens; Dd: Dero digitata; St: Stylaria sp.; T: T. ignotus; TspTSU: Tubifex sp.; Tbe: Tubificoides bermudae; Hh: Heronidrilus heronae; Lv: Lumbriculus variegatus; Hm: Hirudo medicinalis

\section{DISCUSSION}

\section{Taxonomic placement of A1 form and phylogenetic analysis within members of the Myxozoa}

From this study $18 \mathrm{~S}$ rDNA sequence data are provided for an aurantiactinomyxon form (A1). In order to study its taxonomic placement within the phylum Myxozoa, the A1 18S rDNA sequence was compared with those actinosporean/myxosporean related sequences defined by BLAST search and with other available sequences from GenBank. 18S rDNA sequences from members representative of several genera were included (Table 1). Genetic distances and relationships inferred by means of the neighbourjoining method are shown in Fig. 1 and Table 2. The cnidarian fish parasite Polypodium hydriforme was used as outgroup, as previous phylogenetic analyses within the phylum Myxozoa demonstrated that the Cnidaria are the closest ancestors to the Myxozoa (Siddall et al. 1995, Kent et al. 2001).

According mainly to spore morphological criteria, the phylum Myxozoa Grassé, 1970 has been divided into 2 classes: Myxosporea Bütschli, 1881 and Malacosporea. The class Myxosporea has been divided into 2 orders: Bivalvulida and Multivalvulida (Lom \& Dykova 1992). Following this classification, members of the Myxosporea included in this analysis belonged to the order Bivalvulida, Myxidium, Sphaerospora and Ceratomyxa species belonging to the suborder Varii- sporina, and Myxobolus and Henneguya species to the suborder Platysporina. Another myxozoan species included was Tetracapsula bryosalmonae (PKX), recently, included in the class Malacosporea in the order Malacovalvulida (Canning et al. 2000).

Actinosporean parasites were traditionally classified in the class Actinosporea Noble, 1980 within the phylum Myxozoa. Following spore morphology criteria, the class was divided into different families and genera. After the discovery of Wolf \& Markiw (1984), Kent et al. (1994) proposed the suppression of the class Actinosporea and reduction of these genera to the status of collective groups, except for Tetractinomyxon Ikeda, 1912. In the present analysis, Aurantiactinomyxon mississippiensis and 2 marine actinosporeans (Triactinomyxon sp. and Tretraspora discoidea) were included. According to traditional actinosporean classification, the 2 first actinosporeans belong to the family Triactinomyxidae Kudo, 1931, and Tetraspora discoidea, recently assigned according to the similarities of their spores, to the Sphaeractinomyxidae family Janiszewska, 1957 (Hallet \& Lester 1999)

In this study, sequence data and phylogenetic analysis indicate that A1 most closely related to members of the suborder Variisporina. Previous findings based on transmission studies (Kent et al. 1994) and, more recently, cladistic analysis (Xiao \& Desser 2000a) have indicated a relationship between aurantiactinomyxon spore forms and members of the suborder Variisporina. The neighbour-joining dendrogram (Fig. 1), constructed from genetic distance data obtained from species alignments, indicates that A1 most closely relates to Ml18 and Ml19 and to So. From all the sequences compared, the $18 \mathrm{~S}$ rDNA sequence of A1 showed the highest sequence similarities with sequences of these species (79.9\% Ml18, 79.6\% Ml19, $78.6 \%$ So), clustering together in the same branch. This relationship was supported by high bootstrap values of $81 \%$. Several authors, using comparative SSU rDNA sequences analysis, have demonstrated sequence identity between an actinosporean and myxosporean stage, thus revealing different life stages of a myxosporean species (Bartholomew et al. 1997, Andree et al. 1999a, Lin et al. 1999). However, identical sequences to A1 were not found within compared myxosporean species and the life cycle could not be established. These findings suggest that the A1 from this study might be an alternate stage linked with any species of either Myxidium or Sphaerospora.

Morphological features of the spore have been often used to distinguish between members of the phylum Myxozoa. Since the discovery of Wolf \& Markiw 
(1984) of alternate actinosporean/myxosporean stages in the life cycle of Myxobolus cerebralis, and further elucidations on several myxosporean life cycles by transmission studies (Kent et al. 1994), molecular studies have been applied to study the phylogeny on myxosporeans. Recent phylogenetic studies have indicated the unreliability of using only spore morphology in taxonomic purposes. According to these studies other criteria as tissue tropism, geographic location, development and host specificity seems to be better indicators of relatedness than spore morphology. Hervio et al. (1997) showed clustering of different Kudoa species by geographic location rather than by spore morphology, Andree et al. (1999a) demonstrated grouping of Myxobolus spp. better by tissue tropism than by other criteria such as spore morphology or host specificity. Recent taxonomic studies including high number of myxosporean species show that development and tissue location are better indicators of relatedness than spore morphology (Kent et al. 2001).

The general structure of the phylogenetic tree (dendrogram representing the relationship between the compared spores) obtained is conclusive, and consistent with what is known according to previous studies. In regard to the Myxosporea class and in agreement with this classification, the general structure of the tree follows the traditional taxonomic schedule. Relationships were well supported in the analyses with high bootstrap values. The structure of the tree consisted of 2 main branches. Analyzed sequences of members of the suborder Variisporina (Myxidium and Sphaerospora species) cluster together with the organisms of the suborder Platysporina (Henneguya and Myxobolus species); the latter group was found to be more closely related to each other than to the other Variisporina members.

Although the tree supports the separation of the 2 suborders of the Bivalvulida within the Myxosporean class, the data revealed possibly paraphyly within some myxosporean groups. Actinosporean analyses revealed similar results. These arrangements do not support the traditional classification based on morphological criteria of the spores, but support the arrangement of species by tissue location. The phylogenetic tree obtained in this study, including combined sequences of myxosporean and actinosporean stages, showed that (1) Myxobolus cyprini is a member of the Myxobolus genera more closely related to a member of the Henneguya genera (Henneguya salmonicola) than to the other 2 Myxobolus sequences (Myxobolus sp. and M. squamalis). M. cyprini and Henneguya salmonicola are both parasites in muscle occurring in different fish host. These species showed $79 \%$ sequence similarities and clustered together with bootstrap values of $99 \%$. Paraphyly of the genus Myxobolus and Henneguya has been suggested before (Smother et al. 1994, Andree et al. 1999a, Kent et al. 2001) indicating conflicting phylogenetic arrangements of members of the Myxobolus and Henneguya genera. (2) Ml18, Ml19 and So, both coelozoic species, clustered together in a branch. High bootstrap values of $100 \%$ support this arrangement. This type of arrangement has been reported before in phylogenetic studies, where several members of both genera were included (Kent et al. 2001). These authors showed clustering of Sphaerospora species by tissue location.

Aurantiactinomyxon forms included in these studies occur in separated branches, suggesting that there is not a association between actinosporean morphology and myxosporean stage. Aurantiactinomyxon mississippiensis (Am) along with marine actinosporean forms appear within Platysporinid members. A. mississippiensis most related to Henneguya exilis member of the suborder Platysporina, clustering together with 2 marine actinosporeans Triactinomyxon sp. and Tetraspora discoidea; while the A1 from this study clustered together with 2 Variisporina members (see above). The Am sequence showed 96.1\% sequence similarities to Henneguya exilis. These 2 species clustered together with $100 \%$ bootstrap values. Triactinomyxon sp., a marine actinosporean, was most related with Am having sequence similarities of $87.8 \%$ and strong bootstrap support values of $100 \%$, Triactinomyxon sp. and Tretraspora discoidea sequences being $85.1 \%$ similar to each other.

These findings are supported by previous results from more complete molecular studies. Cladistic (Xiao \& Desser 2000a) and riboprinting analyses (Xiao \& Desser 2000b), combining actinosporeans and myxosporean stages, have demonstrated that the Triactinomyxidae family is not a monophyletic group. Grouping of marine actinosporeans with freshwater platysporinids members, and a close relationship of aurantiactinomyxon forms to Henneguya members, have been observed before (Kent et al. 2001).

This study provides an insight into the aurantiactinomyxon A1. Taxonomic placement revealed a closer relationship of A1 with Myxidium lieberkuehni and Sphaerospora oncorhynchi, coelozoic species from different myxosporean genera with high sequence similarities, than to other compared myxosporean sequences. To clarify the taxonomic position of this A1, and to confirm and complement molecular data from this study, further molecular work will be necessary. In this study only a limited number of myxosporean species representative of related genera and actinosporean forms for A1 were included in the phylogenetic analyses. 
The development of A1 of this study within Tubifex ignotus has been now been described by transmission electron microscopy and the fine structure of developmental stages has been demonstrated (Negredo \& Mulcahy 2001b). Results from these investigations gave a basis for comparison with structures of the myxosporean phase. The proposed taxonomy of this aurantiactinomyxon form based on molecular studies is consistent with relationships observed from other electron-microscopic comparative studies. Several ultrastructure similarities with coelozoic species, mainly freshwater species members of the Family Myxidiidae, Thélohan, 1982 (Myxidium, Buetschli, 1882 and Zschokkella Auerbach, 1910) were found which could be understood as in favour of A1's closer relationship with members of these genera. Interesting was the ultrastructure resemblance found with Myxidium giardi (Azevedo et al.1989) such as the polar capsule structure and morphology, features of A1 early stages and $M$. giardi sporoplasm. Similarities of the polar capsules were: the structure of the lucent layer (2 layers forming the lucent wall), spherical shape, and number of filament turns (4 to 5 coils). Similarities of early A1 stages with $M$. giardi sporoplasm were: the nuclear dyplokaryum arrangement with nuclei attaching across a small gap (A1 13 and $15 \mathrm{~nm} M$. giardi) and structure of dense inclusions and sporoplasmosomes.

Studies performed on the myxosporean fauna of the fish on this river system revealed the presence of several myxosporean species of unknown life cycles (O'Flynn 1998). Two Myxidium species, Myxidium giardi from eel Anguilla anguilla and M. rhodei from minnow Phoxinus phoxinus, have been recorded in O'Flynn's (1998) study; in particular $M$. giardi has been found at high prevalence. An aurantiactinomyxon form has been associated with this myxosporean (Benajiba \& Marques 1993). As the 18S rDNA sequence of this actinosporean type and sequences of the Myxidium species are not yet available, the relationship between these myxosporeans and the aurantiactinomyxon type of this study could not be performed.

Marine myxosporean members of the Platysporina or Variisporina groups were not included; therefore, the inclusion of marine actinosporeans within freshwater platysporinids cannot be explained. For a better picture of phylogenetic relationships within the phylum, additional sequences for several members of the different genera and more genera representative of all myxosporean groups (freshwater and marine) should be included. Only a few actinosporean forms were considered, because, at the time of the study, these sequences were the only ones available in the GenBank database.

\section{Phylogenetic analysis of Tubifex ignotus}

Sequence data of the $18 \mathrm{~S}$ rDNA gene from the oligochaete host of aurantiactinomyxon A1, Tubifex ignotus, were generated. In order to analyse the relationship of $T$. ignotus with other tubificids, $18 \mathrm{~S}$ rDNA analyses was performed using several related oligochaete sequences obtained by GenBank BLAST (Table 3). Genetic relationships between related species were inferred by means of the neighbour-joining method (Fig. 2), using the leech Hirudinea medicinalis as an outgroup taxon. An additional oligochaete sequence, for Lumbriculus variegatus, was also used as an outgroup of Tubificidae, based on previous phylogenetic studies (Martin et al. 2000).

The class Oligochaeta within the phylum Annelida consists of several families. Members of the Tubicidae, Naididae and Lumbriculidae families were included in this present analysis, with most of the species belonging to the Tubificidae family. Analyzed members of this family are grouped in 3 subfamilies (Phallodrilinae, Rhyacodrilinae, Tubicinae). Tubifex ignotus, Tubifex sp. and Tubificoides bermudae corresponding to the Tubicinae subfamily, Olavius tantulus and Pirodrilus minutus corresponding to the Phallodrilinae, and Heterodrilus decipiens and Heterodrilus heronae to the Rhyacodrilinae subfamily. Members of the Naididae family included Stylaria lacustris and Dero digitata. Lumbriculus variegatus represented the Lumbriculidae family.

Phylogenetic relationships within oligochaete groups have been assessed using both morphology and molecular data (mitochondrial or $18 \mathrm{~S}$ rDNA sequence data). In most cases, particularly within members of the Tubificidae family, morphological identification proves to be difficult, as it is principally based on morphological characters of its reproductive organs (Brinkhurst \& Jamieson 1971). Thus, sexually mature adults are necessary for identifications. Other important features are the chaetae forms. However, it has been demonstrated in a number of tubificid genera that the forms of chaetae vary (Chapman \& Brinkhurst 1987).

Due to morphological difficulties presented for identification, molecular approaches combined with morphological studies have been used for taxonomy and oligochaete systematics. While 18S rDNA studies have been useful for identification within families (Erséus et al. 2000), 16S mitochondrial studies have been applied to differentiate within genus. Recent molecular studies based on $16 \mathrm{~S}$ mitochondrial rDNA sequences have defined several lineages of morphologically undistinguished species of Tubifex tubifex in Europe and North America (Sturmbauer et al. 1999, Beauchamp et al. 2001) 
In this study, the resulting dendrogram agrees with and supports existing morphological and molecular phylogenetic studies. Most Tubificidae members grouped according to their subfamilies. Tubifex species and Tubificoides bermudae, members of the Tubicinae subfamily, clustered together forming a monophyletic arrangement. This relationship was strongly supported by $95 \%$ bootstrap values. Sequences alignments between these species showed high percentage of sequence identity (99.2 to $99.4 \%)$. Clustering of Olavios tantulus and Pirodrilus minutus, both corresponding to the Phallodrilinae subfamily, was well supported by bootstrap analysis (81\%). Sequence identities observed between these species were $99.1 \%$. Naididae species (Dero digitata and Stylaria lacustris) also formed a monophyletic arrangement, as suggested by bootstrap values (98\%). Sequences similarities were 99\%. The obtained dendrogram indicated paraphyly of the Tubificidae family. It was noticed that members of the Naididae were included within the Tubificidae family, branching with members of the Rhyacodrilinae and Phallodrilinae subfamilies. These arrangements were weak as reflected by the low bootstrap support obtained at the nodes of both branches. A $53 \%$ bootstrap value was obtained at node of branches which separated species of the Tubicinae subfamily from Naididae, and the other Tubificidae species, and $57 \%$ was found between the last 2 groups. Nevertheless, these results are in agreement with morphological (Brinkhurst 1994) and molecular 18S rDNA sequence based phylogenetic studies (Erseus 1990, Erséus et al. 2000). Erséus et al. (2000) suggested the association of Rhyacodrilinae groups with the Naididae taxon.

In conclusion, 18S rDNA sequence data has been obtained for aurantiactinomyxon A1, showing a relationship with 2 coelozoic species of the suborder Variisporina, Myxidium lieberkuehni and Sphaerospora oncorhynchi. Although the complete identity of this aurantiactinomyxon form has not been revealed in this study, the combination of morphological and molecular evidence support its taxonomic placement within the Variisporina, possibly a representative species of the Myxidium genera. It is still uncertain which species A1 represents. High prevalence found for A1 and Myxidium giardi species in the river system and ultrastructural evidences support its relationship with Myxidium giardi. Comparative analyses of $18 \mathrm{~S}$ rDNA genes or other genes will resolve this question in the future.

The 18S rDNA sequence data obtained for its oligochaete host, Tubifex ignotus, will allow reliable identification of this species in the future.

\section{LITERATURE CITED}

Altschul S, Gish W, Miller W, Myers EW, Lipman DJ (1990) Basic Local Alignment Search Tool. J Mol Biol 215: 403-410

Altschul S, Stephen F, Madden TL, Schaffer AA, Zheng Zhang JZ, Miller W, Lipman DJ (1997) Gapped BLAST and PSI-BLAST: a new generation of protein database search programs. Nucleic Acids Res 25:3389-3402

Andree KB, Gresoviac SJ, Hedrick RP (1997) Small subunit ribosomal RNA sequences unite alternate actinosporean and myxosporean stages of Myxobolus cerebralis, the causative agent of whirling disease in salmonid fish. J Eukaryot Microbiol 44(3):208-215

Andree KB, MacConnell E, Hedrick RP (1998) A nested polymerase chain reaction for the detection of genomic DNA of Myxobolus cerebralis in rainbow trout Oncorhynchus mykiss. Dis Aquat Org 34:145-154

Andree KB, Székely C, Molnár K, Gresoviac SJ, Hedrick RP (1999a) Relationships among members of the genus Myxobolus (Myxozoa: Bivalvulida) based on small subunit ribosomal DNA sequences. J Parasitol 85:68-74

Andree KB, El-Matbouli M, Hoffman RW, Hedrick RP (1999b) Comparison of $18 \mathrm{~S}$ and ITS-1 rDNA sequences of selected geographic isolates of Myxobolus cerebralis. Int J Parasitol 29:771-775

Antonio DB, Andree KB, McDowell TS, Hedrick RP (1998) Detection of Myxobolus cerebralis in rainbow trout and oligochaete tissues by using a nonradioactive in situ hybridisation (ISH) protocol. J Aquat Anim Health 10: $338-347$

Azevedo C, Lom J, Corral L (1989) Ultrastructural aspects of Myxidium giardi (Myxozoa, Myxosporea), parasite of the European eel Anguilla anguilla. Dis Aquat Org 6:55-61

Bartholomew, JL, Whipple MJ, Stevens, DG, Fryer JL (1997) The life cycle of Ceratomyxa shasta, a myxosporean parasite of salmonids, requires a freshwater polychaete as an alternate host. J Parasitol 83:859-868

Beauchamp KA, Kathman RD, McDowell TS, Hedrick RP (2001) Molecular phylogeny of tubificid oligochaetes with special emphasis on Tubifex tubifex (Tubificidae) as the host to the fish parasite Myxobolus cerebralis . Mol Phylogenet Evol 19:216-224

Benajiba MH, Marques A (1993) The alternation of actinomyxidian and myxosporidian sporal forms in the development of Myxidium giardi (parasite of Anguilla anguilla) through oligochaetes. Bull Eur Assoc Fish Pathol 13: 100-103

Brinkhurst RO (1994) Evolutionary relationships within the Clitellata: an update. Megadrilogica 5:109-112

Brinkhurst RO, Jamieson BGM (1971) Aquatic Oligochaeta of the world. Oliver \& Boyd, Edinburgh

Canning EU, Curry A, Feist SW, Longshaw M, Okamura B (2000) A new class and order of myxozoans to accommodate parasite of bryozoans with ultrastructural observations on Tetracapsula bryosalmonae (PKX organism). J Eukaryot Microbiol 47:456-468

Chapman PM, Brinkhurst RO (1987) Hair today, gone tomorrow: induced chaetal changes in tubificid oligochaetes. Hydrobiologia 155:45-55

Erséus C (1990) Cladistic analysis of the subfamilies within the Tubificidae (Oligochaeta). Zool Scr 19:57-63

Erséus C, Prestegaard T, Kallersjo M (2000) Phylogenetic analysis of Tubificidae (Annelida, Clitellata) based in 18S rDNA sequences. Mol Phylogenet Evol 15(3):381-389

Hallet SL, Lester RJG (1999) Actinosporeans (Myxozoa) with 4 developing spores within a pansporocyst: Tetraspora 
discoidea n.g. n.sp. and Tetraspora rotundum n. sp. Int J Parasitol 29:419-427

Hervio DML, Kent ML, Kattra J, Sakanari J, Yokoyama H, Devlin RH (1997) Taxonomy of Kudoa species (Myxosporea), using a small subunit-ribosomal DNA sequence. Can J Zool 75:2112-2119

Hillis DM, Dixon MT (1991) Ribosomal DNA: molecular evolution and phylogenetic inference. Q Rev Zool 66:411-453

Jukes TH, Cantor CR (1969) Evolution of protein molecules. In: Muro H M (ed) Mammalian protein metabolism. Academic Press, New York, p 21-132

Kent ML, Margolis L, Corliss JO (1994) The demise of a class of protists: taxonomic and nomenclatural revisions proposed for the protist phylum Myxozoa Grassé, 1970. Can J Zool 72:932-937

Kent ML, Hervio DML, Docker MF, Devlin RH (1996) Taxonomy studies and diagnostic tests for myxosporean and microsporidian pathogens of salmonid fishes utilizing ribosomal DNA sequences. J Eukaryot Microbiol 43(5): 98S-99S

Kent ML, Khattra J, Hervio DML, Devlin RH (1998) Ribosomal DNA sequence analysis of isolates of the PKX myxosporean and their relationship to members of the genus Sphaerospora. J Aquat Anim Health.10:12-21

Kent ML, Andree KB, Bartholomew JL, El-Matbouli M and 12 others (2001) Recent advances in our knowledge of the Myxozoa. J Eukaryot Microbiol 48(4):395-413

Kumar S, Tamura K, Nei M (1993) MEGA: molecular evolutionary genetics analysis, version 1.01. Pennsylvania State University, University Park, PA

Lin DJ, Hanson LA, Pote L (1999) Small subunit ribosomal RNA sequence of Henneguya exilis (Class Myxosporea) identifies the actinoporean stage from an oligochaete host. J Eukaryot Microbiol 46(1):66-67

Lom J, Dyková I (1992) Protozoan parasites of fishes, Elsevier Science Publishers, BV Amsterdam

Lom J, Dyková I (1995) Myxosporea (Phylum Myxozoa). In: Woo PTK (ed) Fish diseases and disorders, Vol 1. Protozoa and metazoan infections. University Press, Cambridge, p 97-148

Marques A (1984) Contribution a la connaissance des Actinomyxidies: ultrastructure, cycle biologique, systematique. $\mathrm{PhD}$ thesis, Universite des Sciences et Techniques du Languedoc, Montpellier

Martin P, Kaygorodova I, Sherbakov D Yu, Verheyen E (2000) Rapidly evolving lineages impede the resolution of phylogenetic relationships among Clitellata (Annelida). Molecular Phylogenet Evol 15(3):355-368

Negredo C, Mulcahy MF (2001a) Actinosporean infections in oligochaetes in a river system in southwest Ireland with descriptions of three new forms. Dis Aquat Org 46:67-77

Negredo C, Mulcahy MF (2001b) The ultrastructure of developmental stages of an aurantiactinomyxon form in the aquatic oligochaete Tubifex ignotus. International Confer-

Editorial responsibility: Wolfgang Körting,

Hannover, Germany ence of the European Association of Fish Pathologists. September 9-14, 2001, Dublin (Abstract)

O'Flynn J (1998) Studies of the biology and lifecycle of PKX, the causative agent of proliferative kidney disease. PhD thesis, University College Cork

Pote LM, Hanson LA, Shivaji R (2000) Small subunit ribosomal RNA sequences link the cause of proliferative gill disease in channel catfish to Henneguya n. sp. (Myxozoa: Myxosporea). J Aquat Anim Health 12:230-240

Saitou N, Nei M (1987) The neighbour-joining method: a new method for reconstructing phylogenetic trees. Mol Biol Evol 4:406-425

Salim KY, Desser SS (2000) Descriptions and phylogenetic systematics of Myxobolus spp. from cyprinids in Algonquin Park, Ontario. J Eukaryot Microbiol 47(3):309-318

Sambrook J, Fritsch EF, Maniatis (1989) Molecular cloning: a laboratory manual, 2nd edn. Cold Spring Harbor Laboratory Press, Cold Spring Harbor, NY

Saulnier D, de Kinkelin P (1997) Polymerase chain reaction primers for investigations on the causative agent of proliferative kidney disease in salmonids. J Fish Dis 20:467-470

Schlegel M, Lom, J, Stechmann A, Bernhard D, Leipe D, Dyková I, Sogin ML (1996) Phylogenetic analysis of complete small subunit ribosomal RNA coding region of $\mathrm{Myx}_{\mathrm{X}}$ idium lieberkuehni: evidence that Myxozoa are Metazoa related to the Bilateria. Arch Protistenkd 147:1-9

Siddall ME, Martin DS, Bridge D, Desser SS, Cone DK (1995) The demise of a phylum of protists: phylogeny of Myxozoa and other parasitic Cnidaria. J Parasitol 81:961-967

Smothers JF, Von Dohlen CD, Smith LH, Spall RD (1994) Molecular evidence that the myxozoan protists are metazoans. Science 265:1719-1721

Sturmbauer C, Opadiya GB, Niederstätter H, Riedmann A, Dallinger R (1999) Mitochondrial DNA reveals cryptic oligochaete species differing in cadmium resistance. Mol Biol Evol 16:967-974

Thompson JD, Higgings DG, Gibson TJ (1994) CLUSTAL W: improving the sensitivity of progressive multiple sequence weighting, position-specific gap penalties and weight matrix choice. Nucleic Acids Res 22:4673-4680

Wolf K, Markiw ME (1984) Biology contravenes taxonomy in the Myxozoa: new discoveries show alternation of invertebrate and vertebrate hosts. Science 225:1449-1452

Xiao C, Desser SS (2000a) Cladistic analysis of myxozoan species with known alternating life-cycles. Sys Parasitol 46:81-91

Xiao C, Desser SS (2000b) Molecular characterization of myxozoan parasites from Lake Sasajewun, Algonquin Park, Ontario, by riboprinting. J Eukaryot Microbiol 47:85-89

Yokoyama H, Owaga K, Wakabayashi H (1991) A new collection method of actinosporeans. A probable infective stage of myxosporeans to fishes from tubificids and experimental infection of goldfish with the actinosporean, Raabeia sp. Fish Pathol 26:133-138

Submitted: March 15, 2002; Accepted: November 18, 2002 Proofs received from author(s): April 11, 2003 